\title{
PERANAN PENDIDIKAN INFORMAL DALAM MENDIDIK ANAK
}

\author{
Evie \\ Jurusan Dharma Duta STAHN-TP Palangka Raya \\ evie@stahntp.ac.id
}

\begin{abstract}
The old parents are the first and the main educator for the children to get the best prince or son. So why the old parents state as the first educator, because the son or the prince birth, growth, and develop in family (informal education). Then the old parents give the first education for the children in order to the children become to the best prince or the best son. The old parents stated as the main educator because the old parents give the main education for their children so become the best prince and the best son. The religion education is very important to the children in informal education. The old parents as the father and as the mother for the children so as the educators in family (informal education). The old parents can realize that very imfortant religion educatian for every member of their family. So They will give positive imfluence to growth and develop of their children. In the other side the children need to understand the religion education to increce the belive of the God, Tuhan Yang Maha Esa, Ida Sang Hyang Widhi Wasa.
\end{abstract}

Keywords: Role, Informal Education, Educate Children

\section{Pendahuluan}

Dalam rangka mewujudkan generasi penerus yang berkualitas agar menjadi pemimpin bangsa yang beriman dan berbakti, berahlak mulia, patriotis, emokratis, mandiri dan tanggap terhadap aspirasi rakyat sangat perlu pendidikan agama. Karena pendidikan agama berkaitan erat dengan bidang yang berhubungan dengan aspek nilai moral dan spiritual. Agama memberikan motivasi hidup dan penghidupan serta merupakan alat pengembangan dan pengendalian diri. Itulah sebabnya pendidikan agama perlu ditanamkan sedini mungkin kepada anak bahkan sejak bayi dalam kandungan. Ada tiga faktor penting mengapa pendidikan agama itu perlu ditanamkan sedini mungkin kepada anak yaitu :

1. Agama memberikan bimbingan dalam kehidupan manusia sejak masih anak-anak dimasa dewasa sampai kepada hari tua agar bermoral luhur dan berperi kehidupan.

2. Agama dapat menolong manusia sejak masa anak-anak agar menjadi seorang yang sabar dan pemikirannya terbuka dalam menghadapi problema dan kesukaran. 
3. Agama dapat membimbing anak agar hidup tenang, jiwa lebih tentram dan terhidar dari godaan serta cobaan.

Sementara dalam kitab Manawa Dharmasastra V.109 disebutkan badan disucikan dengan air, pikiran disucikan dengan satya (kebenaran dan kejujuran). Budhi disucikan dengan jnana atau pengetahuan yang benar. Atman dibersihkan dengan widya dan tapa. Atma widya adalah pengetahuan tentang atma. Sedangkan brahman widya adalah pengetahuan tentang Ketuhanan atau jiwa agung.

Tujuan utama keluarga Hindu "untuk memperoleh putra utama yaitu anak yang nantinya dapat menyelamatkan orang tuanya dan rohroh leluhurnya dari penderitaan dan neraka. Dengan demikian maka anak adalah pelanjut siklus kehidupan keluarga dan lebih luas lagi anak adalah generasi penerus perjuangan bangsa dan merupakan sumber insani bagi pembangunan nasional. Maka oleh sebab itu anak diharapkan mampu menjadi generasi penerus yang berkualitas sebagai sumber daya manusia yang berdaya guna dan berasil guna dalam wadah warisan estapet kepemimpinan bangsa dan negara kesatuan Rebuplik Indonesia.

Ini menggambarkan betapa pentingnya pendidikan agama dari sejak dini dalam sebuah keluarga. Orang tua selain sebagai bapak/ibu bagi anakanaknya sekali gus juga sebagai pendidik dalam pendidikan informal (lingkungan keluarga). Orang tua perlu menyadari betapa pentingnya pendidikan agama bagi setiap anggota keluarganya karna hal itu sangat berpengaruh positif terhadap pertumbuhan dan perkembangan budi pekerti dan kepribadian mereka. Selain itu pula untuk memahami ajaran agama dalam usaha meningkatkan penghayatan terhadap Tuhan dengan menumbuhkan rasa bhakti dalam diri anak perlu melalui pendidik agama yang benar. Demikian pula dalam usaha meningkatkan penghayatan terhadap keagungan Tuhan Yang Maha Esa, Sang Hyang Widhi, dengan menumbuhkan rasa bhaktidalam diri, melalui memahami ajaran agama yang diturunkan-Nya, melakukan segala pekerjaan dan tugas dan kewajiban dengan sepenuh hati serta pemusatan pikiran senantiasa pada-Nya.

Sementara tentang konsep manusia berkualitas menurut kitab Taittiriya Upanisad adalah membangun manusia dari unsur yang paling bawah sampai pada unsur teratas. Mula-mula manusia harus dibangun dari makanan untuk mendapatkan tenaga yang lebih baik kuat (prana) sebagai sumber aktivitas. Selanjutnya membangun pikiran dengan ilmu pengetahuan yang nantinya diharapkan menemukan kebijaksanaan dan kebijaksanaan inilah 
yang akan membawa manusia kearah kebahagiaan.

Orang tua adalah pendidik pertama dan utama bagi anak untuk mendapatkan putra yang suputra. Dikatakan pendidik pertama karena anak yang lahir, tumbuh dan berkembang di dalam keluarga maka orang tualah yang pertama memberikan pendidikan kepada anak agar anak menjadi putra yang suputra. Dikatakan pendidikan utama karena orang tualah yang paling utama dalam mendidik anak-anaknya menjadi putra yang suputra baru orang lain. Selain itu untuk mencapai tujuan hidup dalam agama Hindu menuju jagadhita dan moksa juga diperlukan pendidikan agama. Karena bawasannya agama di turunkan kedunia ini oleh TYME untuk menuntun umat manusia agar mendapatkan kebahagiaan hidup di dunia maupun di alam rohani. Untuk itu dalam tulisan ini akan dilihat bagaimana upaya orang tua dalam membina anak suputra "perspektif pendidikan agama Hindu".

Berdasarkan paparan di atas, maka penulis tertarik mengkaji hala tersebut melalui sebuah masalah yang berjudul "Peranan Pendididkan Informal dalam Mendidikk Anak".

Setiap hal yang kita kerjakan sudah tentu memiliki suatu tujuan. Adapun tujuan yang ingin dicapai dalam Jurnal ini adalah:

1. Untuk mengetahui apa yang pendidikan informal (keluarga)

dalam mendidik anak

2. Untuk mengetahui apa peranan pendididikan informal (keluarga) dalam medidik anak

II. Pembahasan

\subsection{Peranan Pendidikan Informal (Keluarga)}

Orang tua adalah orang yang sudah tua atau berusia 65 tahun keatas setidak-tidaknya orang yang sudah punya anak. Dengan pengertian lain orang tua adalah orang yang sudah tua orang yang dianggap tua baik laki-laki maupun perempuan. Selain itu juga dikatakan sebagai orang tua karna suatu sebab karena ia dikatakan sebagai orang tua, yang dalam hal ini salah satu sebabnya ialah karena orang tersebut sudah berkeluarga dan memiliki anak.

Tanggung jawab dalam suatu keluarga bukan hanya bertangung jawab dalam memenuhi kebutuhan jasmani saja melainkan juga kebutuhan rohaniah. Selain itu tanggung jawab orang tua juga dibidang pendidik yang memberikan pendidikan kepada anakanaknya baik formal, informa dan nonformal. Dan juga memberikan bimbingan kepada anggota keluarganya.

Sedangkan pengertian orang tua, sebagaimana dinyatakan dalam kitab Canakya Nitisastra Bab V Sloka 22 berbunyi :

Janita copaneta ca, yastu visiam prayacchati Anandata bhayatrata, pancipe 
patirah smrtah

(yang menyebabkan lahir, yang

mengalungkan tali suci, yan

mengajarkan ilmu pengetahuan,

yang memberi makan, yang

melindungi dari marabahaya.

Kelima macam ini disebut orang tua).

Dengan demikian jelas orang tua adalah orang yang dianggap tua, orang yang menyebabkan lahir, orang yang menanamkan ilmu pengetahuan, orang yang mengalungkan tali suci, orang yang melindungi dari marabahaya dan orang yang memberi makan dan minum. Pengertian orang tua sebagai orang tua yan memberi ilmu pengetahuan artinya orang tua sebagai guru bagi anakanaknya dan anggota keluarganya yang harus dihormati dan diteladani. Pengertian orang tua disebut sebgai guru rupaka dan guru reka, yaitu guru yan patut digugu perkataannya dan ditiru perkataannya oleh onggota keluarga.

Kartono (1976:174) menyatakan bahwa orang tua adalah penanggung jawab dari lembaga kekeluargaan sebagai suatu integritas anggota keluarga masyarakat, terutama dalam mendidik dan mengajar anak yang belum mampu. Dari pendapat ini jelas oarang tua bertanggung jawab atas kelahiran dan pendidikan anak-anaknya. Kelahiran dan kehadiran seorang anak dalam keluarga memberikan tanggung jawab dari pihak orang tua. Tanggung jawab ini secara garis besar berupa kewajiban untuk memenuhi kebutuhankebutuhan hidup anak, baik materil maupun spirituil yan diperlukan bagi pertumbuhan dan perkembangan putra yang suputra.

Sedangkan pengertian anak suputra berasal dari baha sansekerta dari kata Su dan Putra, "su artinyua baik"sedangkan putra terdiri dari kata put artinya neraka dan ra artinya menyelamtkan. Maka putra artinya ia yang menyelamatkan orang tua dari neraka. Dengan demikian maka suputra adalah anak yang bak, ia dapat menyelamatkan orang tua dan roh-roh leluhurnya dari pendiritaan dan neraka. Anak yang baik dalam vistilah suputra yaitu vanak yang baik bagi dirinya sendiri maupun bagi keluarga, orang lain, bangsa dan negara. Anak yang sehat jasmani dan rohani.

Manusia sebagai salah satu sumber potensi yang menggerakan segala kegiatan pembangunan perlu dididik dan dikembangkan sedini mungkin yakni sejak anak berada dalam kandungan hingga lahir baik segi fisik maupun mentalnya. Ada tiga pusat pendidikan yang disebut dengan Tri pusat pendidikan yaitu keluarga, sekolah dan masyarakat. Keluarga yang dimaksud sebagai salah satu pusat pendidikan adalah ayah dan ibu (orang tua). Ayah dan ibu dalam keluarga adalah unsur pendidik bagi anakanaknya yang pertama dan utama. Ada 
beberapa hal yang perlu diperhatikan dalam upaya orang tua mendidik anak suputra "persepektif pendidikan agama Hindu" yaitu :

\subsection{Mengatur Jarak Kelahiran Anak}

Dalam hal ini, yang perlu diperhatikan adalah umur ideal perempuan mengalami kehamilan yaitu berusia 20 tahun (Pedoman Hidup Sehat Menurut Agama Hindu Dharma, 2001:2). Hal ini sesuai dengan sloka berikut:

Seseorang pelajar wajib menuntut ilmu pengetahuan dan keutamaan. Jika sudah berumur (minimal) 20 tahun, ia boleh/wajar dikawinkan. Jika sudah setengah tua, usahakan berpegang pada ucapan yang baik. Hanya satu yang patut diupayakan yakni berguru tentang hal-hal yang menyebabkan atma Giwa lepas dari kesenangan. (niti sastra, 1986:37).

Dengan mengacu pada syarat dan sloka ini bahwa ajaran agama Hindu tidak menghendaki adanya kehamilan di bawah usia 20 tahun. Hal ini dimaksudkan untuk menjaga kesehatan calon ibu yang akan mengandung dan kesehatan anak yang akan dilahirkan. Ini juga terkandung gagasan untuk mengatur jarak kehamilan misalnya disarankan minimal dalam rentang waktu 2 tahun.

\subsection{Menjaga Kesehatan Ibu Hamil dan Melahirkan}

Untuk mewujudkan kesehatan ibu dan anak, perlu diupayakan dengan memeriksa kandungan secara rutin ke dokter spesialis kandungan atau bidan setempat. Disamping itu perlu diperhatikan beberapa hal yaitu :

1. memperhatikan gizi, ini bermanfaat bagi ibu itu sendiri juga untuk persediaan makan janin yang dikandung.

2. menghindari diri dari rokok dan minuman keras, karena akan dapat berpengaruh pada janin yang dikandung sang ibu.

3. pantang untuk menggugurkan kandungan, dalam ajaran Hindu menggugurkan bayi dalam kandungan dikategorikan sebagai maha petaka atau dosa besar.

4. memeriksa kandungan, hal ini dimaksud untuk mengetahui dan memantau kondisi kandungan, pada waktu-waktu tertentu.

5. menghindarkan kandungan dari gangguan-gangguan pisik seperti benturan-benturan dari luar dan sebagainya.

6. membiasakan diri membaca sastra-sastra agama seperti wiracerita Mahabrata dan Ramayana.

7. partisipasi aktif suami dalam mencurahkan kasih sayang, sehingga sang istri akan lebih merasakan keamanan atau ketentraman batin. 
2.4. Memperhatikan Pertumbuhan dan Perkembangan Anak

Lingkungan keluarga sangat mempengaruhi pertumbuhan dan perkemabangan anak. Meliputi hubungan suami istri, hubungan orang tua dan ank, antara saudara, suasana keluarga, besarnya keluarga dan cara mengasuh anak. Dalam hal in perlu diperhatikan adalah kehadiran ibu di tengah-tengah keluarga yang dapat menghasilkan rasa aman dan tentram pada seluruh anggota keluarga terutama pada anak-anak.

Yang dibutuhkan oleh anak dalam proses berkembangnya buka hanya pemuasan materi saja, melainkan yan lebih penting adalah rohaniah ibunya yang setiap saat diperlukan ada didekatnya, sehingga banyak memberikan perhatian terhadap anak. Seorang iu sangat berperan penting dalam mengasuh anak. Dari kasih sayang ibulah anak itu tumbuh dan berkembang menjadi putra yang suputra.

\subsection{Memberikan Pendidikan} Agama Hindu Pada Anak

Pendidikan agama bagi anak bertujaun membentuk kepribadian yang didalamnya terjalin nilai-nilai keimanan yan selanjutnya menjadi pengarah dan pengendali bagi prilakunya serta dapat selalu mengadakan pilihan yang terbaik yaitu sesuai dengan ketentuan Tuhan dalam hidupnya. Pendidikan agama
Hindu dalam keluarga sangatlah perlu karena keluargalah satu-satunya lembaga pendidikan yang mampu melakukan keberimanan bagi anakanaknya karena anak lebih banyak waktunya berada di lingkungan keluarga. Melakukan pendidikan agama dalam keluarga berarti ikut menyelamatkan generasi muda. Keimanan dan ketaqwaan itulah yang akan menerangi kehidupan anak itu kelak dikemudian hari. Keimanan dan ketaqwaan itulah yang akan menjadi filter dalam menilai mana yang baik dan mana yang buruk dalam bergaul, berkata dan berbuat.

Ada dua tahap dalam memberikan pendidikan agama Hindu kepada anak, yaitu :

1. Tahap Pranatal (sebelum lahir)

Pembinaan mental anak dapat diberikan pada masa kehamilan dengan cara memberikan bimbingan keagamaan pada calon orang tua terutama ibunya. Ibu memegang peranan penting dalam pendidikan mental anak semasa dalam kandungan karena itulah dalam agama Hindu diajarkan bahwa setiap ibu yang sedang mengandung hendaknya dapat berpikir, berkata dan berbuat baik sesuai ajaran trikaya parisudha serta melaksanakan upacara-upacara suci. Upacara-upacara yang yang bisa dilaksanakan pada saat bayi dalam kandungan sebagai pendidikan kepada calon anak adalah : 
1. upacara garbhadhana yaitu upacara yang dilaksanakan saat terjadinya pertemuan kama bang (sperma) dan kama petak (sel telur) yang merupakan cikal bakal benih dari kehamilan seorang anak. Dengan benih yang suci diharapkan anak yang lahir berkualitas suputra.

2. upacara sinantonaya, yaitu upacara ini diadakan setelah kandungan si ibu berumur 4 atau 5 bulan. Secara psikologi bahwa pada bulan ini mekanisme otak janin sudah mulai berfungsi sehingga pemisahan rambut di kepala sang ibu bisa memberikan rangsangan dari luar.

3. upacara pegedong-gedongan, yaitu setelah kandungan berumur tujuh bulan, upacara ini dimaksudkan untuk mendoakan si bayi agar kelak lahir dengan selamat dan nantinya menjadi manusia yang suputra.

2. Tahap Postnatal (sesudah lahir)

Setelah anak dilahirkan, orang tua harus melanjutkan kewajiban mendidik anak-anaknya, yaitu dari bayi lahir sampai dewasa. Agar pendidikan tersebut berdaya guna dan berhasil guna maka pendidikan diterapkan secara berjenjang sesuai dengan kondisi pertumbuhan fisik dan perkembangan psikis anak yan bersangkutan. Sebagaimana dalam niti sastra (1086:35) sargah IV.20 berbunyi:

Anak yang sedang berumur lima tahun, hendaknya diperlakukan seperti anak raja. Jika sudah berumur tujuh tahun dilatih supaya suka menurut. Jika sudah sepuluh tahun diajari membaca. Jika sudah enam belas tahun diperlakukan sebagai sahabat; kalau kita mau menunjukan kesalahnnya haruslah dengan hati-hati sekali jika ia sendiri sudah beranak diamati saja tingkahnya; kalau hendak memberi pelajaran kepadanya cukup dengan gerak dan isyarat.

Hal ini menunjukan bahwa dalam membina dan mendidik anak dalam rangka mewujudkan anak yang berkualitas suputra, maka orang tua harus dapat melihat perkembangan fisik maupun mental si anak. Dalam masingmasin jenjang tersebut digunakan sistem tertentu yang didasarkan pada kondisi yang sedang dialami oleh anak, sehingga adanya keselarasan antara jenjang, sistem dengan kondisi pisik dan kemampuan/daya pikir anak sehingga diharapkan pendidikan dapat berhasil menelurkan anak yang suputra.

Dalam ajaran agama Hindu sistem pendidikan mental pada anak yang telah lahir selai dididik untuk melakukan kebiasaan-kebiasaan baik juga dapat dilakukan melalui upacara-upacara suci, sebagai mana dalam weda smerti (1976/1977:68) Bab II sloka 27 menyatakan sebagai berikut:

Dengan upacara membakar baubauan yang harum pada waktu 
kehamilah, dengan upacara jatakarma (bayi waktu lahir), upacara cauda (gunting rambut pertama), dan upacara maunji bandhana (upacara memberi kalung/gelang) maka kekotoran yang didapat dari orang tua akan hilang.

Dari kitipan sloka diatas menunjukan bahwa upacara-upacara suci agama yang dilaksanakan bagi anak mulai dari kandungan sampai anak itu lahir hingga tumbuh dewasa, disamping mengandung makna filosofis juga pada hakekatna bertujuan untuk memelihara serta mendidika mental si anak dan sebagai pensucian lahir batinnya. Upacara-upacara agama yang diadakan setelah anak lahir adalah :

1. jatakarma upacara bayi baru lahir. Upacara ini dilaksanakan agar sang bayi mendapat keselamatandan merupakan cetusan rasa bahagia dari orang tua.

2. upacara ngelepas hawon (namadheya) adalah upacara pemberian nama.

3. u p a c a r a n y a m butin (niskramana) upacara yang dilakukan setelah anak menginjak tiga bulan upacara ini dimaks udkan sebagai persembahan kepada Hyang Surya (matahari) oleh karen itu upacara ini dianggap sebagai yang pertamakalinya anak berhubungan dengan kekuatan alam.

4. upacara satu oton/ngotonin (anaprasana) samskara adalah upacara dilakukan setelah anak berusia 6 buln. Pada upacara ini dilakukan pemotongan rambut yang pertama untuk sibayi dan pada bagian ubun-ubun (siwadwara) rambutnya masih ditinggalkan sedikit karena masih lemah. Ini sebagai peringatan kelahiran sang bayi bertujuan untuk memohon perlindungan keselamatan dan kesucian.

5. upacara munggah deha/teruna /raja sewala adalah upacara bagi anak menginjak dewasa terutama bagi anak perempuan bertujaun untuk memohon petunjuk kehadapan Sang Hyang Semara Ratih beserta widiadari agar beliau memberikan bimbingan secara gaib sehingga anak mengendalikan dirinya dalam menghadapi masa pancaroba.

6. upacara mepandes (potong gigi) yaitu untuk mengendalikan dari pengaruh sad ripu. Agar menjadi manusia yang sejati dan memenuhi kewajiban orang tuanya terhadap sianak.

Selain itu masih banyak caracara yang bisa dilakukan dalam upaya 
mendapatkan anak suputra dalam pandangan pendidikan agama Hindu. Namun dalam tulisan ini baru mencobasecara garis besarnya saja upaya orang tua dalam mendidik anak suputra "perspektif pendidikan agama Hindu.

\section{Simpulan}

Dalam rangka mewujudkan generasi penerus yang berkualitas agar menjadi pemimpin bangsa yang beriman dan berbakti, berahlak mulia, patriotis, demokratis, mandiri dan tanggap terhadap aspirasi rakyat sangat perlu pendidikan agama. Karena pendidikan agama berkaitan erat dengan bidang yang berhubungan dengan aspek nilai moral dan spiritual. Agama memberikan motivasi hidup dan penghidupan serta merupakan alat pengembangan dan pengendalian diri.

Orang tua adalah pendidik pertama dan utama bagi anak untuk mendapatkan putra yang suputra. Dikatakan pendidik pertama karena anak yang lahir, tumbuh dan berkembang di dalam keluarga maka orang tualah yang pertama memberikan pendidikan kepada anak agar anak menjadi putra yang suputra. Dikatakan pendidikan utama karena orang tualah yang paling utama dalam mendidik anak-anaknya menjadi putra yang suputra baru orang lain. Ada tiga pusa pendidikan yang disebut dengan Tri pusat pendidikan yaitu keluarga, sekolah dan masyarakat. Keluarga yang dimaksud sebagai salah satu pusat pendidikan adalah ayah dan ibu (orang tua) adalah unsur pendidik bagi anakanaknya. beberapa hal yang perlu diperhatikan dalam upaya orang tua mendidik anak suputra "persepektif pendidikan agama Hindu" yaitu: 1) Mengatur jarak kelahiran anak; 2) Menjaga kesehatan ibu hamil dan melahirkan; 3) Memperhatikan pertumbuhan dan perkembangan anak; dan 4) Memberikan pendidikan agama Hindu pada anak

Dalam satu keluarga disarankan agar orang tua menjaga kesehatan jasmani dan rohani anak karena dalam tubuh yang sehat terdapat jiwa yang sehat. Hingga diharapkan pula kepada orang tua memberikan pendidikan agama Hindu kepada anak sejak anak dalam kandungan hingga dewasa melalui pendidikan mental dan peneladanan. Diharapkan pula orang tua melaksanakan upacara agama bagi anak sejak dalam kandungan hingga lahir dan dewasa.

\section{Daftar Pustaka}

Ahmadi, Abu. Ilmu Sosial Dasar.

Rineka Cipta: Jakarta. 2003

Departemen Agama RI. Pola

Pembinaan Lembaga

Keagamaan Hindu. Proyek 
Pembinaan Lembaga

Keagamaan: Jakarta. 1996

Departemen Agama RI. Modul

Keluarga Bahagia Sejahtera.2001

Husaini, Usman. Metodologi Penelitian

Sosial. Bumi Aksara: Jakarta.2004

Netra, Anak Agung Gde Oka, Drs.

Tuntunan Dasar Agama Hindu. 1994

Netra, Anak Agung Gde Oka Drs.

Brosur Pembinaan Remaja

Hindu. Departemen Agama RI

Ditjen Bimas Hindu Budha:

Jakarta.1998

Mantra, Ida Bagus, Prof.Dr., Tata

Susila Hindu Dharma. Hanuman, 1993

Megawangi, Ratna,. Pendidikan

Karakter untuk Membangun

Masyarakat Madani. IPPK

Indonesia: Jakarta.2003

Sinaga, Anggiat M. Dan W.K., Sri

Hadiati.Pemberdayaan Sumber

Daya Manusia.Lembaga

Administrasi Negara: Jakarta.

2001

Sukardika, Kadek. Menata Bali Ke

Depan, Kebijakan Kultural,

Pendidikan dan Agama. Bali

Media Adhikarsa: Denpasar.

2004

Sanafiah, Faisal. Format-format

Penelitian Sosial. Raja

Grafindo Persada: Jakarta. 2005

Titib, I Made. VEDA SABDA SUCI :

Pedoman Praktis Kehidupan.

Paramitha: Surabaya.1996

Tim Penyusun. Pedoman Tenaga
Pembina Agama

Hindu.Hanuman Sakti: Jakarta.

1994

Tim Penyusun UU RI No.20.Tentang

Sistem Pendidikan Nasional.

Aneka Ilmu: Semarang: 2003 
Jurnal Penerangan Agama Hindu Vol. 15 No. 2, 2017 